\title{
Barriers and Facilitators to Implement Preventive Practices to Drug Abuse ${ }^{1}$
}

\author{
Erika Pizziolo Monteiro ${ }^{2}$, Henrique Pinto Gomide 3 , Pedro Henrique Antunes da Costa ${ }^{4}$, \\ Pollyanna Santos da Silveira ${ }^{5}$, Telmo Mota Ronzani ${ }^{4}$ \\ ${ }^{2}$ Universidade Federal do Rio Grande do Sul, Porto Alegre-RS, Brazil \\ ${ }^{3}$ Universidade Federal de Viçosa, Viçosa-MG, Brazil \\ ${ }^{4}$ Universidade Federal de Juiz de Fora, Juiz de Fora-MG, Brazil \\ ${ }^{5}$ Universidade Católica de Petrópolis, Petrópolis-RJ, Brazil
}

\begin{abstract}
In the Brazilian context, the Prevention Course to Drug Use for Public School Educators is developed. This study seeks to identify factors cited by the educators as favorable or unfavorable to the implementation of prevention projects. Data collection was carried out in three stages: in the first stage (T0), a sample consisted of 1494 course participants, in the second stage (T1), 2153 teachers participated and in the third stage (T2), 1017 educators answered the questions. Text mining techniques and content analyses were used. The results were categories proposed for the axes barriers and favorable aspects: training of school team, students and school community relationship and participation of the community and perceived dysfunctional family aspects, violence and drug trafficking, personal characteristics of adolescents and the school environment, respectively. The identification of these aspects is relevant to the development of prevention programs, allowing barriers to be anticipated and solutions to be proposed.
\end{abstract}

Keywords: drug abuse prevention, teacher education, program development

\section{Barreiras e Facilitadores para Implementação de Práticas Preventivas ao Abuso de Drogas}

Resumo: No contexto brasileiro, desenvolve-se o Curso de Prevenção ao Uso de Drogas para Educadores de Escolas Públicas. O presente estudo teve por objetivo identificar fatores citados pelos educadores-cursistas como favoráveis ou desfavoráveis à implementação de projetos de prevenção. A coleta de informações foi realizada em três momentos: no primeiro momento (T0), a amostra foi composta por 1494 cursistas. No segundo momento (T1), 2153 cursistas participaram e no terceiro momento (T2), 1017 educadores responderam às questões. Foram utilizadas técnicas de mineração de texto e análise de conteúdo. Como resultados foram propostas as categorias barreiras e aspectos favoráveis, sendo essas: capacitação da equipe escolar, relação entre alunos, comunidade escolar e participação da comunidade, aspectos familiares disfuncionais, violência e tráfico de drogas, características pessoais dos adolescentes e o ambiente escolar, respectivamente. A identificação destes aspectos é relevante ao desenvolvimento de programas de prevenção, permitindo que barreiras sejam antecipadas, propondo-se soluções para elas.

Palavras-chave: prevenção do abuso de drogas, formação de professores, desenvolvimento de programa

\section{Barreras y Facilitadores para la Aplicación de Prácticas Preventivas al Abuso de Drogas}

\begin{abstract}
Resumen: En el contexto brasileño, se desarrolla el Curso de Prevención de Consumo de Drogas para Educadores Públicos. Se busca identificar los factores citados por los educadores como favorables o desfavorables para la realización de proyectos de prevención. La recolección de datos se sucedió en tres etapas: la primeira (T0), con 1494 participantes, en la segunda etapa (T1), 2153 educadores participaron y en la tercera etapa (T2), con 1017 educadores. Se utilizaron técnicas de minería de texto y análisis de contenido. Se propusieron categorías para barreras y aspectos favorables: la formación del personal escolar, relación entre estudiantes y la comunidad escolar, la participación de la comunidad y, aspectos disfuncionales de la familia, la violencia y el tráfico de drogas, las características personales de los adolescentes y el entorno escolar, respectivamente. Esta identificación es relevante para el desarrollo de programas de prevención, permitiendo que las barreras sean anticipadas, proponiéndose soluciones a ellas.
\end{abstract}

Palabras clave: prevención del abuso de drogas, formación de profesores, desarrollo de programa

\footnotetext{
${ }^{1}$ Article derived from the master's thesis of the first author under the supervision of the last author, defended in 2015, in the Postgraduate Program in Psychology of the Universidade Federal de Juiz de Fora. Support: Coordination for the Improvement of Higher Education Personnel (CAPES Grant \# 1420985); Foundation for Research Support of the State of Minas Gerais (FAPEMIG - Grant \# CBB APQ 03256/13); Productivity Scholarship of the National Council for Scientific and Technological Development (CNPq - Grant \# 301542/2016-3).

Correspondence address: Erika Pizziolo Monteiro. Universidade Federal do Rio Grande do Sul. Programa de Pós-Graduação em Psicologia, Rua Ramiro Barcelos, 2600, Campus Saúde. Porto Alegre-RS, Brasil. CEP 90.035-003. E-mail: erikapizziolo@gmail.com
}

Abuse or dependence of alcohol and other drugs is a public health condition with consequences in several areas. Actions directed towards substance use can be carried out in different phases, either through actions that promote healthy behaviors, preventive activities of abuse and dependence, or actions directed to the care of dependents that present physical symptoms and psychological and social problems (Perlman \& Jordan, 2017). Studies to establish rates of alcohol and other drug use in Brazil have been carried out in order to assess the extent of the issue, identifying problems associated with substance use by children and adolescents and, 
thus, justifying the development of interventions for the phenomena associated with substance abuse (Madruga et al., 2012).

In a review of the United States literature on prevention programs (Winters, Fawkes, Fahnhorst, Botzet, \& August, 2007), some elements have been identified as effective components in the planning and implementation of prevention programs for adolescents. The existence of a school curriculum that addresses cross-cutting themes and activities aimed at modifying psychosocial risk factors is necessary, developing continuous preventive actions that have the potential to maximize positive effects. The activities developed must also have goals and language adapted to the context, thus promoting the engagement of the target population to the interventions, as well as their families. With regard to the professionals responsible for directing the intervention, due to the proximity of teachers to their students during an important period of their development, several interventions are present in the literature in which teachers are the facilitators of prevention activities (Moreira, Vóvio, \& De Micheli, 2015; Rohrbach, Graham, \& Hansen, 1993).

There are numerous publications on evidence-based prevention practices, pointing to positively evaluated program models (Griffin \& Botvin, 2010). Although there are guidelines for interventions aimed at reducing the consumption of alcohol and other drugs in school contexts to achieve satisfactory results, the expected results are not always attained (United Nations [UN], 2004). There are some reasons for this to occur, among which one may mention the fact that the phenomenon of alcohol and other drugs use is complex and requires planning of the actions developed, seeking to work on contextual aspects of the problem. Thus, interventions directed only at dissemination of information do not present satisfactory results (Coggans, 2006). To develop specific interventions, a deep understanding of the nature of the problem is required, training the school team on the issue, and planning ways to assess the process and results of the prevention projects implemented (Anderson, 2011).

Regarding the nature of the problem in each context of intervention, one must search for information about the students' substance use pattern, about beliefs and attitudes regarding alcohol and other drugs use among adolescents involved in the intervention process, about risk and protection factors that may exert an influence on the behaviors, on the interests that the students have in relation to their health process, on updated and efficient intervention techniques. Finally, it is necessary to investigate the phenomenon of the use of alcohol and other drugs broadly in the context in which the intervention is intended (Morton, Hoefinger, Linn-Walton, Aikins, \& Falkin, 2015). The development of evaluation culture of programs to prevent risk behaviors and health promotion is ideal, so that the implementation process, as well as the data produced, are systematically evaluated, seeking to produce practices based on scientific evidence (Barry, Clarke, Jenkins, \& Patel 2013; Gorman, 2014).

Currently, one of the strategies used to sensitize and train professionals on the subject of alcohol and other drugs are e-learning courses designed to build knowledge based on scientific evidence to intervene on the issue in some way, either through the application of community-based interventions or projects focused on the school context, among others (Cruvinel, Souza, Mota, \& Ronzani, 2013; Secretaria Nacional de Políticas sobre Drogas [Senad], 2012).

The present study includes a series of evaluations on the Prevention Course to Drug Use for Public School Educators conducted by the National Secretariat for Drug Policy (Senad). The course, operated as a distance education initiative, aimed to enable Brazilian public school educators to work with the prevention of the use of alcohol and other drugs based on information consistent with the scientific literature in the area. Further details about the course and its modules are described in an earlier study conducted by researchers from the team responsible for the training process (Monteiro, Gomide, Silveira, \& Ronzani, 2016).

Considering the extent to which e-learning or distance education courses proposals have spread, it is necessary that such initiatives be subject to periodic evaluation processes. Monitoring the effectiveness of programs is important to (a) justify the initial investment of resources; (b) ensure that goals are being met; (c) improve both processes and results; and (d) provide a basis for decisions to continue, expand, or discontinue programs (Thompson \& Irele, 2003).

Considering the scenario described above, the present study aimed to identify and describe factors cited by educators as favorable or unfavorable to the implementation of prevention projects in the school context.

\section{Method}

\section{Participants}

All active educators in the training process were invited to respond to the research tools available in the Virtual Learning Environment (VLE). The information collection was carried out in three moments of the construction process of the prevention projects. For the first stage (T0) of the present study, the research questions were answered in a discursive way by 1494 students. At the end of the fourth module of the course, the second stage of the research (T1), 2153 students participated, while in the third stage (at the end of the fifth module; T2) 1017 students answered the questions proposed. In the second and third stages, the questionnaires were composed of closed questions.

For the characterization of the course participants, data collected during the training course were combined, so that among 2153 students who answered the first questionnaire (T1), sociodemographic information was found for 705 $(32 \%)$. These had an average age of 46.1 years $(S D=7.8)$, the majority $(85 \%)$ being female. With regard to occupation, $70.6 \%$ were teachers, $4.34 \%$ were directors, $3.95 \%$ were supervisors and $3.16 \%$ were pedagogical coordinators (19.89\% made up the other professionals of the school team). 


\section{Instruments}

To fulfill the objectives, research questionnaires were made available to educators in the Virtual Learning Environment (VLE). To compose the questionnaires, we sought to construct research items aiming at identifying the favorable and unfavorable aspects of the prevention project's implementation process. The questions used to collect information were: (1) "What are the possible barriers to the prevention project being implemented in practice?" and (2) "What are the factors that contribute to the implementation of the prevention project?".

\section{Procedure}

Data collection. The procedures described below were carried out within the scope of the Prevention Course to Drug Use for Public School Educators, as previously mentioned. The theoretical stage of the training process was directed to the construction of projects to prevent the abusive use of alcohol and other drugs in the school context. In this sense, the first four theoretical modules of the course had as their final objective the construction of a project and the last module (Module 5) was directed to the implementation process of this project in the school context (Senad, 2012).

The present study was carried out in stages during the whole period of the course. The first stage, which was called Phase 1, consisted of the development and application of the discursive activities written by the educators in the Virtual Learning Environment (VLE), with the objective of identifying the perceived aspects as facilitators and obstacles to the development of prevention projects. In the second and third stages, which was called Phase 2, the facilitators and difficulties identified in the previous phase were presented to the participants in multiple choice questions at two different moments (T1 and T2) to investigate whether the categorization process conducted in the previous phase was performed correctly. Below, both steps of the investigative process are described.

Phase 1. The projects for the prevention of alcohol and other drug use proposed by the educators enrolled in the course were built in stages, so the process involved planning and implementation of the activities outlined. To identify possible barriers and facilitating aspects of project execution, 1494 responses were created by the educators in a discursive activity proposed at the end of Module 2 of the course. The database with the answers to the two questions (What are the possible barriers for the prevention project to be implemented in practice? What are the factors that contribute to the implementation of the prevention project?) was imported into the programming language $\mathrm{R}$ and analyzed using strategic functions for performing text mining techniques.

This database was filtered through the removal of white space, numbers and scores of the answers provided by the educators-students (course's students), as well as the frequent words of the language - stopwords (Porter, 2014), as articles and prepositions irrelevant to the comprehension of the text.
After this stage, statistical analyses were carried out with word radicals and complete words. For pre-classification, the most frequent words were identified (frequency greater than 200) and, therefore, the elements that made difficult or easier the implementation of prevention projects more cited by the educators at the time of the task.

To finish the process that allowed the identification of the facilitating and difficult aspects to the prevention project's implementation, correlation analyses between the most frequent words were carried out to identify which were the most related terms and guide the construction of the categories. At the same time, to identify how the words related to each other, a technique of grouping the most cited words was used, generating graphic information that presented, in a schematic way, how they were related in texts created by educators (Lantz, 2013).

The results of the analyses performed by the statistical software were used to identify the items cited as potentialities and barriers to prevention actions. Then, these items went through a process of horizontal categorization (Bardin, 2010), through which they were grouped into categories forming each axis (Axis 1: facilitators to the execution process of actions; Axis 2: difficulties in the process of executing actions).

Phase 2. Once identified the aspects cited as facilitators and obstacles to the process of execution of prevention actions, these were used in the form of options for answers to the same research questions made available in phase 1 of the methodological process (What are the possible barriers for the prevention project to be implemented in practice? What are the factors that contribute to the implementation of the prevention project?).

The first moment of information collection for Phase 2 (T1) happened at the end of Module 4, period in which the prevention projects were delineated, and the second collection moment (T2) happened at the end of the course during the module directed to the implementation of the prevention actions.

Data analysis. In order to achieve the objectives proposed in this article, quantitative and qualitative data analysis techniques were used. The quantitative strategies were descriptive, correlational and grouping, being performed through the language R (R Core Team, 2015), as previously mentioned, to apply the text mining techniques. The qualitative techniques were applied to the process of reading the words identified by the statistical software as more frequent and correlated, through the perspective of content analysis, generating items that were grouped into categories forming two thematic axes, the first being composed of three categories and the second by four categories, which will be presented below (Bardin, 2010).

\section{Ethical Considerations}

The present study is linked to a larger project called "Training and Evaluation of Public School Educators for Drug Use Prevention among Adolescents", evaluated and approved by the Research Ethics Committee of the Federal University of Juiz de Fora (Universidade Federal de Juiz de 
Fora - UFJF) through report number 787,766. We used, for data analysis, the activities of the course's educators who voluntarily agreed to the Free and Informed Consent Term and answered the activities and questionnaires made available in the Virtual Learning Environment during the course.

\section{Results}

\section{Phase 1}

The results from the analyses used during the text mining process described in the Procedures - Data Collection section (Phase 1) started from two sets of statistical analyses descriptive and correlational - made in order to generate information on the favorable and unfavorable aspects to the implementation process of the prevention projects (Figure 1).

The following items were extracted from the relationships between words and translated as aspects favorable to the implementation of the prevention projects, based on the grouping of the aspects pointed out by the educators as facilitators, being: students with an interest in the subject, presence of a team to work on the theme, encouragement to students, healthy relationship between student-family-school- community, development of projects in school, support for projects in development, presence of rules in the school environment, respect in the teacher-student relationship, promotion of commitment and trust, community and parent participation in prevention work (Figure 2).

Based on the grouping of the words pointed out by the educators as obstacles to the project implementation process, as shown above, the following items of barriers to the development of prevention projects were generated: absence of the family, lack of communication with parents, use of substances by relatives, presence of illicit drugs in the school environment, proximity to the drug distribution network, absence of students' boundaries, absence of students in school, absence of school team collaboration, absence of rules in the school environment.

As a way of organizing the information obtained during this article, we chose to group favorable aspects and barriers to the development of preventive actions in two axes, through a process of horizontal categorization (Bardin, 2010). In order to fulfill this objective, the criterion of similarity between the items was followed, seeking among them possibilities of common sense, in order to find categories that explained in general the positive resources and barriers reported by the educators. The table below shows, in schematic form, the axes and the categories formed (Table 1).

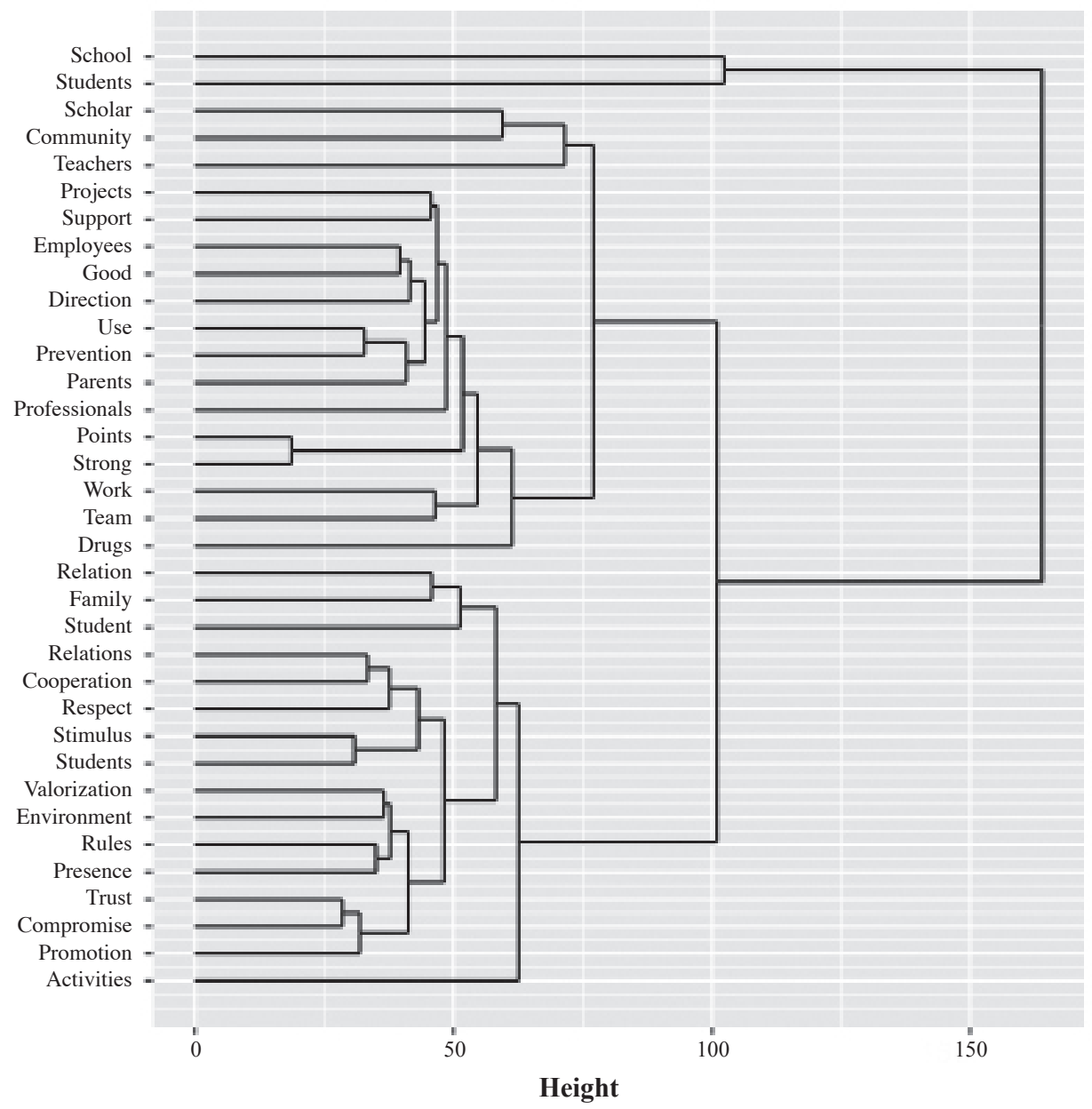

Figure 1. Grouping of the aspects cited as facilitators of project implementation to prevent the use of alcohol and other drugs by adolescents. 


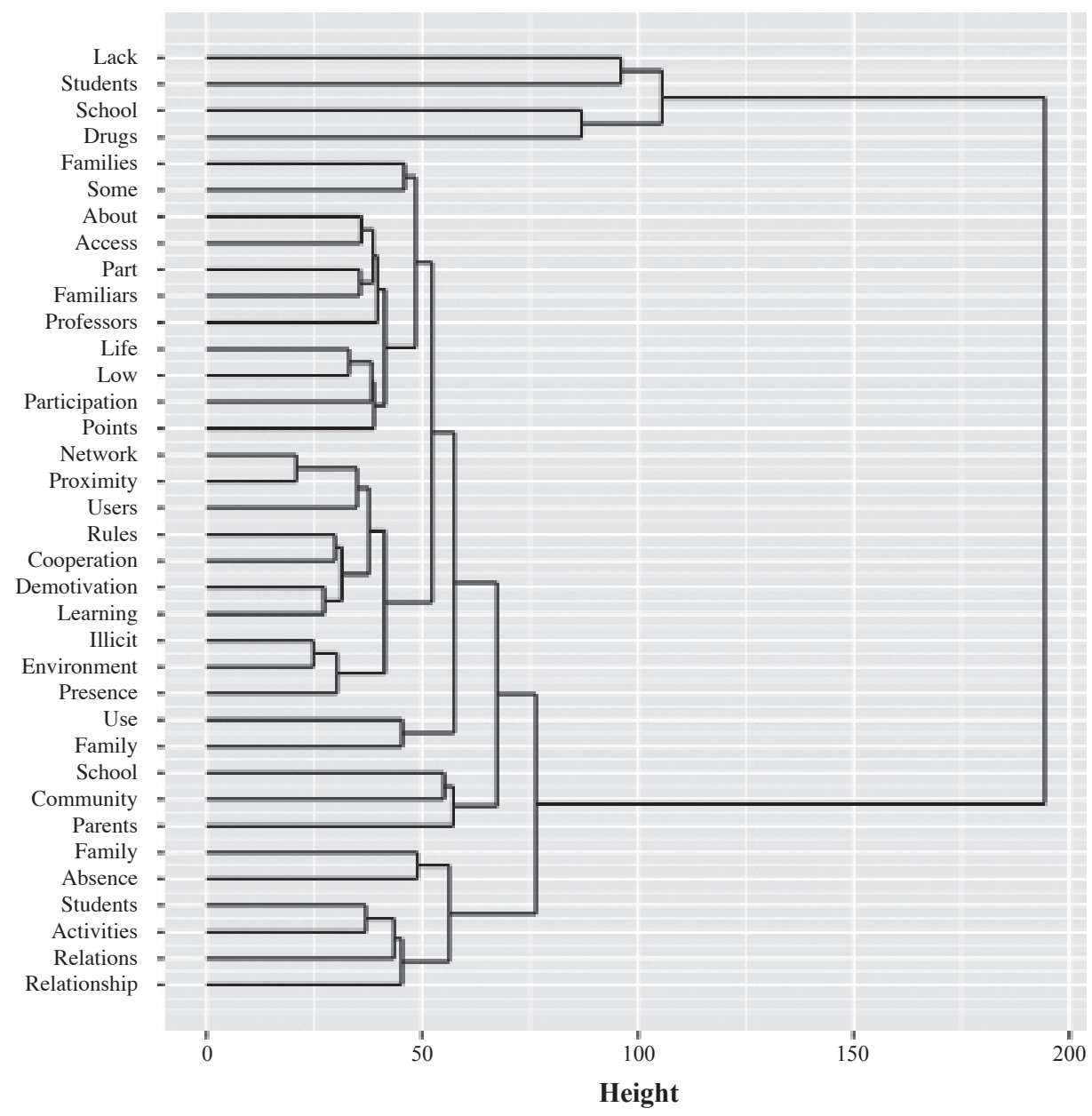

Figure 2 - Grouping of aspects cited as obstacles of project implementation to prevent the use of alcohol and other drugs by adolescents.

Table 1

Items and categories of potentialities and difficulties for prevention projects

\begin{tabular}{ll}
\hline \multicolumn{1}{c}{ Categories } & \multicolumn{1}{c}{ Items } \\
\hline Training and awareness of the school team & Presence of a team to work on the thematic \\
& Development of projects in the school \\
& Support for projects in development \\
Relationship students-school-community & To have students interested in the subject \\
& Encouraging students \\
& Presence of rules in the school environment \\
& Respect in teacher-student relationship \\
Participation of the general community in the process & Promoting commitment and trust \\
& Healthy relationship between student-family-school-community \\
& Community and parent involvement in prevention work
\end{tabular}

Axis 2. Difficulties in the implementation of projects to prevent the use of alcohol and other drugs

\begin{tabular}{ll}
\hline Family aspects perceived as dysfunctional & $\begin{array}{l}\text { Absence of the family } \\
\text { Little communication with parents }\end{array}$ \\
& Use of substances by relatives \\
Violence and drug trafficking & $\begin{array}{l}\text { Presence of illicit drugs in the school environment } \\
\text { Proximity of the drug distribution network }\end{array}$ \\
& $\begin{array}{l}\text { Lack of student boundaries } \\
\text { intended }\end{array}$ \\
School environment & $\begin{array}{l}\text { Absence of students in school } \\
\text { Lack of school team collaboration }\end{array}$ \\
& Absence of rules in the school environment \\
\hline
\end{tabular}




\section{Phase 2}

Once the aspects considered by the educators were identified as favorable and unfavorable to the implementation process, these items were made available to the students during modules 4 (T1) and 5 (T2), as described in the Procedures - Data collection section (Phase 2). Descriptive tables were created in order to present the results found for the items that comprised both axes of analysis in the two moments of data collection (Table 2 and Table 3 ).

Table 2

Frequency of the facilitators perceived by the educators before and after the preparation of the project

\begin{tabular}{lcc}
\hline Favorable Item & Before (\%) & After (\%) \\
\hline $\begin{array}{l}\text { Development of projects } \\
\begin{array}{l}\text { Presence of a team to work on the } \\
\text { subject }\end{array}\end{array}$ & 57.9 & 67.5 \\
$\begin{array}{l}\text { Respect in teacher-student } \\
\text { relationship }\end{array}$ & 47.1 & 66.4 \\
$\begin{array}{l}\text { Stimulus to students } \\
\text { Promoting commitments and trust }\end{array}$ & 43.8 & 55.3 \\
$\begin{array}{l}\text { Support for projects } \\
\text { Presence of rules in schools }\end{array}$ & 40.7 & 51.8 \\
$\begin{array}{l}\text { Community and parental } \\
\text { involvement }\end{array}$ & 37.6 & 44.7 \\
$\begin{array}{l}\text { Healthy relationship student-family- } \\
\text { school-community }\end{array}$ & 49.6 & 31 \\
\begin{tabular}{l} 
Students interested in the subject \\
\hline
\end{tabular} & 43.7 & 32.7 \\
\hline
\end{tabular}

Table 3

Frequency of the barriers perceived by the educators before and after the elaboration of the project

\begin{tabular}{lcc}
\hline Unfavorable Item & Before (\%) & After (\%) \\
\hline Absence of family & 65.1 & 68.4 \\
Drug use of relatives & 62.4 & 624 \\
Poor communication with parents & 37.4 & 51.6 \\
Absence of student boundaries & 35.3 & 35 \\
Drug trafficking & 27.8 & 38.5 \\
Absence of team collaboration & 27.4 & 20.6 \\
Presence of drugs in the school & 12.8 & 19.2 \\
environment & 12.4 & 14.6 \\
Absence of rules for the students & 7.2 & 14.9 \\
Absence of the student in the school &
\end{tabular}

The results show that, in a general way, there was an increase in the perception of the factors pointed out as potentialities and barriers to the process of implementation of preventive actions in the educator's school contexts, between the periods of construction of the proposal and execution of the actions.
The participation of the community and parents, healthy student-family-school-community relationships, the presence of students interested in the subject, lack of student's boundaries and absence of team collaboration items were the only ones less mentioned during the second evaluation period (T2) for Phase 2, when compared to the frequencies obtained during the development period of the prevention projects (T1). Using the second phase of procedures to investigate a second research problem related to the development and implementation times of prevention projects, it was expected that the frequency with which the barriers were reported by the participants would be maximized. This is due to the fact that the third moment of data collection was carried out during the process of implementation of prevention projects in the educational contexts of the educators, therefore, a critical phase for the emergence of difficulties. The results showed that there was a considerable increase in perception of "poor communication with parents" and "drug trafficking", while for other items there was a small reduction or a small increase in frequency. The increase in the perception of some difficulties raises the discussion about the limit of scope of the training course, since for many of the schools represented there was only one educator enrolled in the course, making difficult the process of creation and implementation of new practices. It is emphasized, however, that such expectations and their confirmations or refutations are analyzed in the light of a qualitative approach to production and interpretation of results.

\section{Discussion}

From the analysis of data, some issues were highlighted and transcribed into categories that formed two axes. The first axis concerns the potential of the construction process of preventive practices, involving the following categories: training and sensitization of the school team, relationship between students and the school community, and the participation of the general community in the process. The second axis concerns the existing barriers to the process, classified as: family aspects perceived as dysfunctional, violence and drug trafficking, characteristics of the children/ adolescents to whom the projects are intended and, finally, school environment.

As favorable factors to the execution of preventive practices to the use of alcohol and other drugs in the school context, aspects related to the need of the sensitization processes and the qualification of the professionals were cited, corroborating the literature in the area related to the construction of projects based on perspectives and activities considered to be effective in preventing drug use (Collier \& Henriksen, 2012). Thus, the perception of educators about the issue should be considered and addressed in formative processes that aim the development of effective practices in the school environment. Tobler et al. (2000), in a review carried out on the effectiveness of prevention practices, points out that universal interactive programs have the highest success rates, being an important aspect of this success the availability of teachers to address cross-cutting themes, such as, the use of alcohol and other drugs. Educators should 
encourage the capacity for critical reflection in their students, so that they can understand their contexts comprehensively and consciously (Albertani \& Sodelli, 2014).

Considerations about the relevant role of teachers in the process of training their students leads to the other point cited as a facilitator of the implementation process of prevention projects, described as the relationship established between children/adolescents and school team, indicating that positive relationships should be constructed between educators and their students, evaluating the perception of both on a complex phenomenon such as the use of alcohol and other drugs. In this context, the school community is cited as support for the development of activities, relying on the fundamental role of principals in order to support the planning and execution of programs in school contexts, and having the role of helping to form a critical conscience in the students - characteristic of a school team's responsibilities (Albertani \& Sodelli, 2014).

For prevention programs to the use alcohol and other drugs to reach the objectives they are aiming for, contextual factors must be considered so that the planning and conduction of activities is directed at the characteristics of their target audience, thus, a community perspective of potential partner's involvement in the construction of actions helps in more promising results (Sarriera, 2015).

In a review conducted by Canoletti and Soares (2005), research reports on prevention programs developed in Brazil between 1991 and 2001 indicate that the target audience for the interventions are children and adolescents or the teachers responsible for the development of future preventive work. Given this scenario, it is noticed that the emphasis given to the participation of potential partners in the development of educational practices is neglected, making it necessary to include actors who can be essential to the success of interventions by sharing their perspectives and stories.

Regarding the factors identified as barriers to the implementation of prevention projects, aspects related to the personal, family and environmental context of children and adolescents were cited by the educators. In this sense, we can see the influence of several areas and contexts in the development of preventive activities in the school. Some points may be considered as risk factors for substance use and, consequently, may impair the success of interventions aimed at preventing alcohol and other drug abuse (Sartes, Gumier, Fernandes, \& Ferreira, 2014). Schenker and Minayo (2005) point out that factors such as vulnerability of individuals, family relationships, group pressure and the school environment itself can be considered as risk and, therefore, should be addressed in actions directed at children and adolescents. It is emphasized here that such factors were cited by the educators as issues of their daily lives.

Specifically on the role of the family, or in its absence in the school space, as well as its functionality, as mentioned by the educators participants in this research, it is highlighted that it was addressed during the training course through the discussion forums - one of the activities that composed the framework of tasks - points that could foster a critical discussion based on scientific studies on the role of the family in contributing to the healthy development of children and adolescents, respecting the individual characteristics of parents and guardians, and their individual, cultural and social baggage (Mangueira \& Lopes, 2014).

Socio-cultural factors influence the way in which the use of alcohol and other drugs is viewed and addressed, so the model that bases the interventions must consider the context in question, going beyond an environmental perspective in which the influence of contextual aspects is understood in a simplistic way, considering it only as peer pressure, for example (Schneider, 2010). Thus, factors such as violence, drug trafficking, involvement of those responsible for alcohol and other drug use, or the existence of a school environment without resources should be considered in an expanded manner and in constant dialogue in order to construct interventions that can at least discuss social aspects in a critical and open way, allowing children and adolescents to become active in their training process, protagonists of concrete actions and multipliers of healthy practices (Paiva \& Costa, 2014). Interventions aimed at children and adolescents should be interactive, allowing them to participate and explain their experiences and visions on various current issues, thus considering the most productive characteristics of their target audience in order to contribute to their quality of life.

In general, it can be said that prevention practices can have satisfactory effects and contribute significantly to the process of training children and adolescents in a context of Brazilian public education. Efforts to continue to train educators to assist them in the task of raising awareness and educating young people are fundamental in the process of building quality education provision, assessing the process of sensitization and training in a systematic way to present contextualized and suitable perspectives. In this sense, the results presented in the present article can be used in the planning of future training aimed at educators, instrumentalizing them for the execution of prevention activities. Through this perspective, barriers to the development of programs can be anticipated, seeking more efficient solutions.

This article highlights the process of mining the data cited as favorable and unfavorable to the process of construction of preventive actions. Due to the inherent characteristics of distance-learning, many professionals are involved in the process, making it difficult to analyze all texts produced in a purely qualitative way. Thus, an alternative form (data mining) was developed to identify the items that summarized the difficulties and positive points found by educators enrolled in the Prevention Course to Drug Use for Public School Educators, followed by the process of data categorization (Bardin, 2010). To use this approach it is necessary to investigate the adequacy between the text mining techniques used and the intended objectives in order to produce methodologically based data.

The procedures for identifying potentialities and barriers to the process of implementing preventive actions in school contexts were carried out in two different periods of the process to investigate the perception of these variables during 
the construction of the proposal and during the execution of the activities, as previously mentioned. It was hoped that the difficulties would be cited more frequently during the implementation period as day-to-day aspects of the prevention project would be put into practice. However, the perception of the course's students about the potentialities and difficulties was, in a general way, balanced between the two moments of data collection. Thus, it is concluded that since the construction of preventive activities, there are challenges and aspects that contribute to the development of preventive actions.

From the research process described in this article and its consequent results, it is pointed out the relevance of methodologies to identify the possible problems and potentialities of prevention work in school environments in order to maximize the existing advantages, search for viable solutions to the barriers encountered and develop contextual preventive programs. In terms of the process of constructing the research, innovative methodologies, such as the application of data mining techniques, propose new ways of dealing with distinct objectives and research objects, and it is necessary that such approaches be disseminated, replicated and evaluated in other contexts of scientific research. In practical terms, using the strategy of continuing education to address issues of social relevance, such as abusive use of alcohol and other drugs, which affect the contexts of action of various professionals, such as school environments, is appropriate and important both for the quality of the service rendered and the possible impact on the individuals benefited by the new practices implemented.

\section{References}

Albertani, H. M. B., \& Sodelli, M. (2014). Drogas e educação: A escola (real) e a prevenção (possível) [Drugs and education: School (real) and prevention (possible)]. In T. M. Ronzani \& P. S. Silveira (Orgs.), Prevenção ao uso de álcool e outras drogas [Preventing the use of alcohol and other drugs] (pp. 133-155). Juiz de Fora, MG: Editora UFJF.

Anderson, D. S. (2011). New directions for substance-abuse prevention. Change: The Magazine of Higher Learning, 43(6), 46-55. doi:10.1080/00091383.2011.618082

Bardin, L. (2010). Análise de conteúdo [Content analysis] (L. A. Reto \& A. Pinheiro, Trans.). Lisboa, Portugal: Edições 70.

Barry, M., M., Clarke, A. M., Jenkins, R., \& Patel, V. (2013). A systematic review of the effectiveness of mental health promotion interventions for young people in low and middle income countries. BMC Public Health, 13, 835. doi:10.1186/1471-2458-13-835

Canoletti, B., \& Soares, C. B. (2005). Programas de prevenção ao consumo de drogas no Brasil: Uma análise da produção científica de 1991 a 2001 [Drug consumption prevention programs in Brazil: Analysis of the scientific production from 1991 to 2001]. Interface - Comunicação, Saúde, Educação, 9(16), 115-129. doi:10.1590/S1414-32832005000100010
Coggans, N. (2006). Drug education and prevention: Has progress been made? Drugs: Education, Prevention and Policy, 13(5), 417-422. doi:10.1080/09687630600812882

Collier, C., \& Henriksen, R. C., Jr. (2012). Teachers' perceptions of a multiple high-risk behavior prevention program and delivery of universal programming. The Qualitative Report, 17(50), 1-19. Retrieved from http:// www.nova.edu/ssss/QR/QR17/collier.pdf

Cruvinel, E., Souza, I. C. W., Mota, D. C. B., \& Ronzani, T. M. (2013). Disseminação e implementação de ações de prevenção [Dissemination and implementation of prevention actions]. In T. M. Ronzani (Org.), Ações integradas sobre drogas: Prevenção, abordagens $e$ políticas públicas [Integrated action on drugs: Prevention and public policy approaches] (pp. 325-354). Juiz de Fora, MG: Editora UFJF.

Gorman, D. M. (2014). Is project Towards No Drug Abuse (Project TND) an evidence-based drug and violence prevention program? A review and reappraisal of the evaluation studies. The Journal of Primary Prevention, 35(4), 217-232. doi:10.1007/s10935-014-0348-1

Griffin,K.W.,\&Botvin, G.J.(2010).Evidence-basedinterventions for preventing substance use disorders in adolescents. Child and Adolescent Psychiatric Clinics of North America, 19(3), 505-526. doi:10.1016/j.chc.2010.03.005

Lantz, B. (2013). Machine learning with R. Birmingham, United Kingdom: Packt.

Madruga, C. S., Laranjeira, R., Caetano, R., Pinsky, I., Zaleski, M., \& Ferri, CP. (2012). Use of licit and illicit substances among adolescents in Brazil - a national survey. Addictive Behaviors, 37(10), 1171-1175. doi:10.1016/j.addbeh.2012.05.008

Mangueira, S. O., \& Lopes, M. V. O. (2014). Família disfuncional no contexto do alcoolismo: Análise de conceito. Revista Brasileira de Enfermagem, 67(1), 149154. doi:10.5935/0034-7167.20140020

Monteiro, E. P., Gomide, H. P., Silveira, P. S., \& Ronzani, T. M. (2016). Curso de prevenção ao uso de drogas: Descrição e avaliação de satisfação [Prevention of drug use course: Description and satisfaction evaluation]. Estudos de Psicologia (Natal), 21(3), 328-336. doi:10.5935/1678-4669.20160031

Moreira, A., Vóvio, C. L., \& De Micheli, D. (2015). Drug abuse prevention in school: Challenges and possibilities for the role of the educator. Educação e Pesquisa, 41(1), 119-135. doi:10.1590/S1517-97022015011670

Morton, C. M., Hoefinger, H., Linn-Walton, R., Aikins, R., \& Falkin, G. P. (2015). What are youth asking about drugs? A report of NIDA drug facts chat day. Journal of Drug Educaion, 45(3-4), 195-210. doi: $10.1177 / 0047237915622084$ 
Paiva, F. S., \& Costa, P. H. A. (2014). Participação juvenil: Uma alternativa para se abordar o uso de drogas no espaço escolar [Youth participation: An alternative approach to the use of drugs at school]. In T. M. Ronzani \& P. S. Silveira (Orgs.), Prevenção ao uso de álcool e outras drogas [Preventing the use of alcohol and other drugs] (pp. 113-132). Juiz de Fora, MG: Editora UFJF.

Perlman, D. C., \& Jordan, A. E. (2017). Considerations for the development of a substance-related care and prevention continuum model. Frontiers in Public Health 5, 180. doi:10.3389/fpubh.2017.00180

Porter, M. (2014). Snowball. Retrieved from http://snowball. tartarus.org/

R Core Team. (2015). R: A language and environment for statistical computing. Vienna, Austria: The R Project for Statistical Computing. Retrieved from http://www.rproject.org/

Rohrbach, L. A., Graham, J. W., \& Hansen, W. B. (1993). Diffusion of a school-based substance abuse prevention program: Predictors of program implementation. Preventive Medicine, 22(2), 237-260. doi:10.1006/pmed.1993.1020

Sarriera, J. C. (2015). Psicologia comunitária: Estudos atuais [Community psychology: Current studies] (4a ed.). Porto Alegre, RS: Sulina.

Sartes, L. M. A., Gumier, A. B., Fernandes, L. R., \& Ferreira, M. L. (2014). Fatores de risco e de proteção para o uso de álcool e outras drogas [Risk factors and protection for the use of alcohol and other drugs]. In T. M. Ronzani \& P. S. Silveira (Orgs.), Prevenção ao uso de álcool e outras drogas [Preventing the use of alcohol and other drugs] (pp. 91-112). Juiz de Fora, MG: Editora UFJF.

Schenker, M., \& Minayo, M. C. S. (2005). Fatores de risco e de proteção para o uso de drogas na adolescência [Risk and protective factors and drug use among adolescence]. Ciência \& Saúde Coletiva, 10(3), 707-717. doi:10.1590/ S1413-81232005000300027

Schneider, D. R. (2010). Horizonte de racionalidade acerca da dependência de drogas nos serviços de saúde: Implicações para o tratamento [Horizon of rationality about drug addiction in the health services: Implications for treatment]. Ciência \& Saúde Coletiva, 15(3), 687698. doi:10.1590/S1413-81232010000300011

Secretaria Nacional de Políticas sobre Drogas. (2012). Curso de prevenção do uso de drogas para educadores de escolas públicas [Course on drug abuse prevention for public school educators]. Brasília, DF: Editora UnB.

Thompson, M. M., \& Irele, M. E. (2003). Evaluating distance education programs. In M. G. Moore \& W. G. Anderson (Eds.), Handbook of distance education (pp. 567-584). Mahwah, NJ: Lawrence Erlbaum.
Tobler, N. S., Roona, M. R., Ochshorn, P., Marshall, D. G., Streke, A. V., \& Stackpole, K. M. (2000). Schoolbased adolescent drug prevention programs: 1998 metaanalysis. The Journal of Primary Prevention, 20(4), 275 336. doi:10.1023/A:1021314704811

United Nations. (2004). Schools: School-based education for drug abuse prevention. New York, NY: Author. Retrieved from https://www.unodc.org/pdf/youthnet/handbook school_english.pdf

Winters, K. C., Fawkes, T., Fahnhorst, T., Botzet, A., \& August, G. (2007). A synthesis review of exemplary drug abuse prevention programs in the United States. Journal of Substance Abuse Treatment, 32(4), 371-380. doi:10.1016/j.jsat.2006.10.002

Erika Pizziolo Monteiro is a Ph.D candidate of the Universidade Federal do Rio Grande do Sul, Porto AlegreRS, Brazil.

Henrique Pinto Gomide is a Professor of the Centro de Ciências Humanas, Letras e Artes of the Universidade Federal de Viçosa, Viçosa-MG, Brazil.

Pedro Henrique Antunes da Costa holds a Ph.D from the Universidade Federal de Juiz de Fora, Juiz de Fora-MG, Brazil.

Pollyanna Santos da Silveira is a Professor of the Universidade Católica de Petrópolis, Petropólis-RJ, Brazil.

Telmo Mota Ronzani is a Professor of the Universidade Federal de Juiz de Fora, Juiz de Fora-MG, Brazil.

\section{Authors' Contribution:}

All authors made substantial contributions to the conception and design of this study, to data analysis and interpretation, and to the manuscript revision and approval of the final version. All the authors assume public responsability for content of the manuscript.

Received: Sep. 05, 2016

1st Revision: Apr. 01, 2017

Approved: Oct. 27, 2017

How to cite this article:

Monteiro, E. P., Gomide, H. P., Costa, P. H. A., Silveira, P. S., \& Ronzani, T. M. (2018). Barriers and facilitators to implement preventive practices to drug abuse. Paidéia (Ribeirão Preto), 28, e2835. doi: http://dx.doi.org/10.1590/1982-4327e2835 